\title{
Aquifer characteristics and groundwater recharge pattern in a typical basement complex, Southwestern Nigeria
}

\author{
B. S. Badmus ${ }^{1 \star}$ and O. B. Olatinsu ${ }^{2}$ \\ ${ }^{1}$ Department of Physics, University of Agriculture, Abeokuta, Nigeria. \\ ${ }^{2}$ Department of Physics, University of Lagos, Lagos, Nigeria.
}

Accepted 18 March, 2010

\begin{abstract}
A geophysical survey involving thirty four vertical electrical sounding (VES) was carried out at Federal College of Education, Osiele, Abeokuta, southwestern Nigeria using Schlumberger electrode array. The locations were selected based on the existing boreholes drilled in the past within the study area. The results revealed a maximum of five geoelectric layers, viz: topsoil, sandy clay, clayey sand, shale/clay, sandstone, fractured basement and fresh basement. Three probable aquifer units and one aquitard were delineated with clayey sand occurring in $50 \%$, sandy clay constitutes $24 \%$, fractured basement $24 \%$ and shale/clay $2 \%$. VES 10,26 and 30 with weathered layer (shale/clay) of thicknesses $14.7,23.5$ and $9.9 \mathrm{~m}$ respectively revealed very low yield (not productive). Borehole drilling in the study area should be executed in the peak of the dry seasons during which groundwater level is expected to be low because recharge of the existing boreholes in the study area is largely due to falling precipitation. Existing boreholes located within the study area characterized by unconfined aquifer while some are confined under pressure between relatively impermeable materials. With this, the problems of recharging and drying up of borehole can be solved.
\end{abstract}

Key words: Resistivity, fractured basement, lithology, aquifer, geoelectric layers.

\section{INTRODUCTION}

Fractured crystalline bedrock aquifers are good sources of potable water in many parts of the world. However, sitting of highly productive wells in these rock units remains a challenging and expensive task because fracture development at the regional scale is both heterogeneous and anisotropic (Manda et al., 2006). Using low cost electrical resistivity data to determine units of rock that have similar lithologic and fracture characteristics can greatly reduce time, cost and energy spent on determining areas with better than average aquifer productivity. Basement aquifers are developed within the weathered overburden and fractured bedrock of crystalline rocks of intrusive and/or metamorphic origin which are mainly of Precambrian age (Wright, 1992).

Groundwater development may be primarily restricted to the aquifer in the weathered overburden or completed

\footnotetext{
*Corresponding author E-mail: badmusbs@yahoo.co.uk
}

in the fractured bedrock in locations where the overburden is relatively thin. Viable aquifers wholly within the fractured bedrock are of rare occurrence because of the typically low storativity of fracture systems (Clark, 1985). An intrinsically low porosity limits the quantity of water stored in fractured crystalline rock. Sustainable well yields for bedrock, therefore, may strongly depend on the quantity of water stored in surficial materials that can leak downward into bedrock and on periodic replenishment by recharge (Lyford, 2004).

This study presents the use of electrical resistivity method in the delineation of bedrock structures, depth to possible aquifer units and to infer the groundwater potential of the basement complex area. This work becomes very necessary as a result of: (i) the frequent high failure rate of boreholes, being much higher where the weathered overburden is thin; (ii) shallow occurrence and fissure permeability of the bedrock aquifer unit which makes for susceptibility to surface contaminants; and (iii) the low storage capacity of fractured aquifers which are 


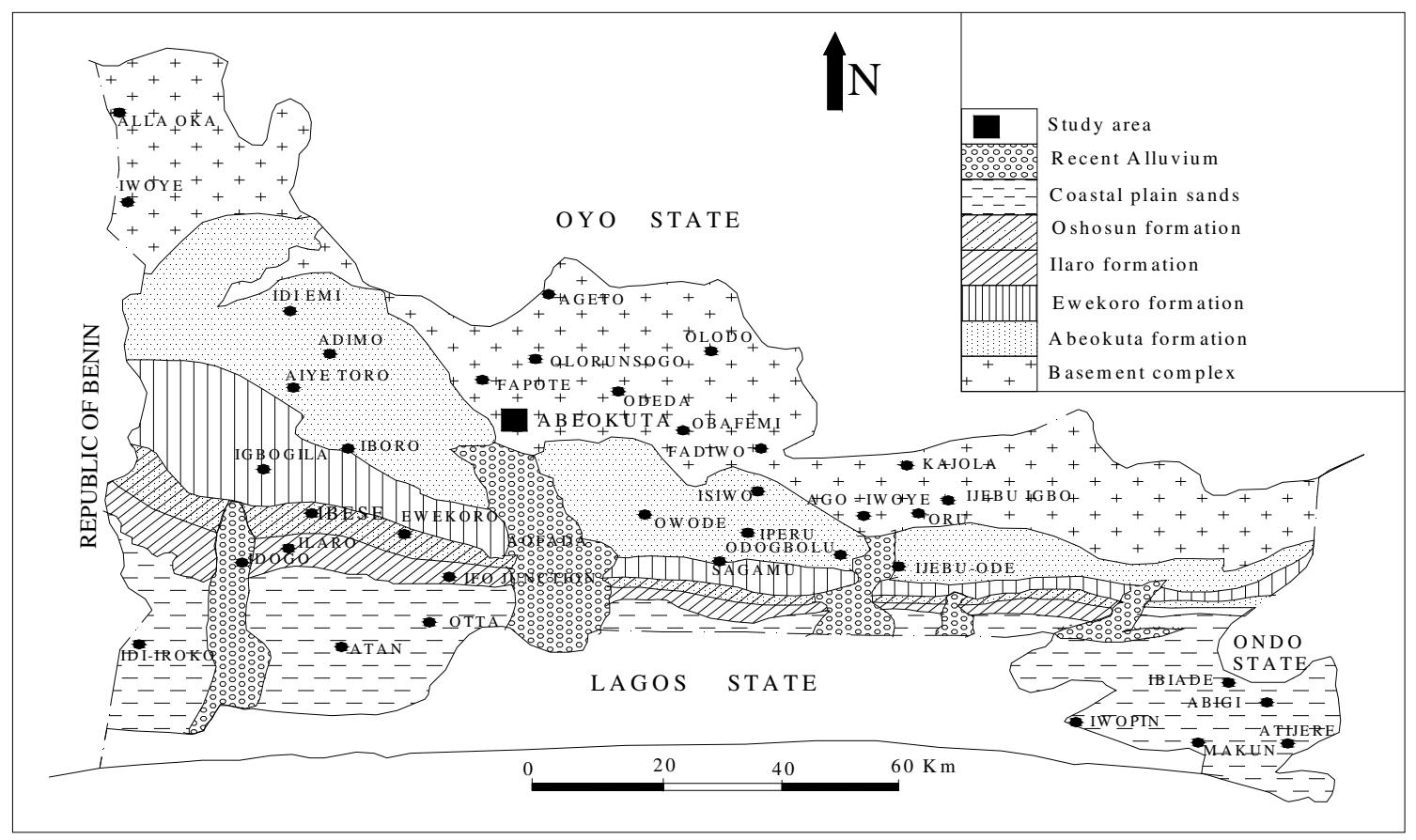

Figure 1: Geological map of Ogun State, showing the study area.

easily depleted during dry seasons. Therefore to meet the ever increasing demand of water in the study area, there is need for a detailed geophysical survey so as to site viable locations for withdrawal wells. This will also require understanding the geologic and hydrogeologic characteristics of the crystalline bedrock as well as the regional tectonic setting which are critical to identifying favourable areas to site large groundwater wells (Talkington, 2004).

\section{Physoigraphy, geology and hydrogeology}

The study area is the Federal College of Education, Osiele, Abeokuta, Southwestern, Nigeria. The area falls under the Basement Complex area of Ogun State, Southwestern Nigeria (Figure 1). The basement rocks comprise of folded gneiss, schist, quartzite, older granite, and amphibolites/mica schist (Jones and Hockey, 1964, Rahman, 1975). The occurrence of groundwater in crystalline rocks depends on the extent and depth of weathering and fracturing. Basement aquifers are developed within either the regolith (relatively high storativity but low permeability) or the fractured bedrock (low storage capacity with a relatively high permeability). The groundwater is contained in the weathered/ fractured formations and is primarily recharged through surface precipitation and secondarily through lateral flow from rivers and tributaries.

\section{Climate and vegetation}

The study area falls within the humid tropical region which is characterized by wet and dry seasons. The wet season usually occur from March to October and is dominated by heavy rainfall. The dry season occurs from November to March when the area is under the influence of North-easterly winds. The annual rainfall is estimated to be about $1600 \mathrm{~mm}$. The mean monthly temperature ranges between $25.7^{\circ} \mathrm{C}$ in July and $30.2^{\circ} \mathrm{C}$ in February, and the average annual temperature is $26.6^{\circ} \mathrm{C}$. High humidity (generally above $50 \%$ ) and long wet season ensures adequate supply of water and continuous presence of moisture in the air. Hence, the study area is characterized by high diurnal and annual temperature, lack of cold season, high precipitation, low pressure, high evapo-transpiration and high relative humidity.

\section{Data acquisition and processing}

Thirty four (34) vertical electrical sounding were carried out at different locations within the study area, using the ABEM 300 SAS Terrameter. The electrode arrangement was Schlumberger with electrode separation of $200 \mathrm{~m}$. The VES locations were chosen very close to the existing boreholes at a distance of between 1.0 and 2.0 $\mathrm{m}$ in most cases while few are along the traverse of these existing boreholes.

The layouts of the VES locations are as shown in data acquisition map (Figure 2). From the field data, the apparent resistivity values were computed by multiplying the geometric factor with the field resistivity values. Data processing was carried out with the use of WingLink, software developed by GEOSYSTEM. This was used to mask individual data points, create smooth and layered inversion model for each VES station. The final results are summarized in Tables 1 and 2.

\section{RESULTS AND DISCUSSION}

\section{VES analysis}

The VES analysis shows a minimum of three and a maximum of five geoelectric layers which compose of the 


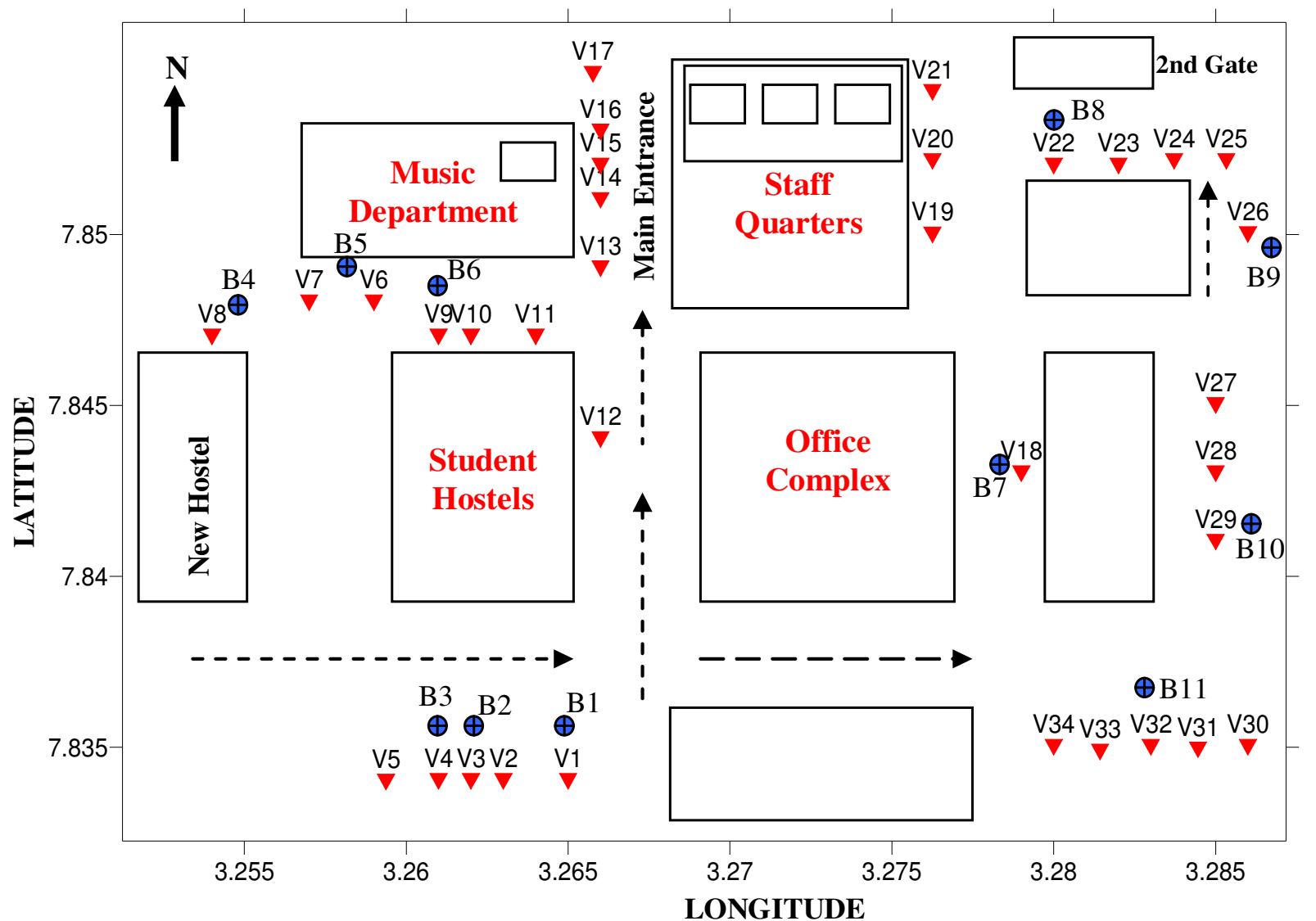

\section{Legend}

$\oplus_{\text {Borehole }} \quad \nabla_{\text {VES Points }}$

LONGITUDE

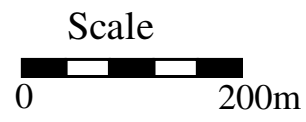

Figure 2. Data acquisition map of the study location.

following lithologies: topsoil, shale/clay, sandy clay, clayey sand, sandstone, fractured bedrock and fresh bedrock as depicted in the geoelectric sections (Figures $3 a-g)$.

The study area was divided into seven profiles. Profile I consists of VES $1-5$. Clayey sand with resistivity value $398 \Omega \mathrm{m}$ and thickness $28.6 \mathrm{~m}$ as revealed in VES 1 is inferred as the most probable aquifer unit along this profile. Profile II with VES $6-11$ also has clayey sand of resistivity value $600 \Omega m$ in VES 9 , indicating good aquifer unit.

The thickness could not be determined but the depth to this aquifer is $31.4 \mathrm{~m}$. At profile III which com-prises of VES 12 - 17, sandy clay layers with resistivity values 132 , 103 and $107 \Omega \mathrm{m}$ and thicknesses 15.8, 23.9 and $26.9 \mathrm{~m}$ at VES 14, VES 15 and VES 17 are the likely aquiferous units along this profile. These locations are not recommended for borehole drilling due to the sandy clay nature. Profile IV with VES 18 - 21 has an aquifer unit in VES 19. This has fractured bedrock of resistivity $843 \Omega \mathrm{m}$ and depth to this layer is $37.9 \mathrm{~m}$.

Sandy clay with resistivity $104 \Omega \mathrm{m}$ and thickness 18.6 $\mathrm{m}$ in VES 25 is the main aquifer unit along profile $\mathrm{V}$ which consists of VES 22 - 25. At profile VI where VES $26-29$ are located, clayey sand layer with resistivity $388 \Omega \mathrm{m}$ at a depth of $24.5 \mathrm{~m}$ in VES 28 is a good aquifer unit along this section. The overburden thickness at profile VII is generally small. The clayey sand with resistivity value $512 \Omega \mathrm{m}$ at a depth of $8.2 \mathrm{~m}$ could still be prospective borehole location (Tables 1 and 2).

\section{Recharge pattern}

Recharge is important not only on account of the small storage capacity of basement aquifers but also because a better understanding of the processes and amount involved increases the knowledge of the occurrence and potential (Wright, 1992). Recharge, as it relates to groundwater, is simply the replenishment condition of 
Table 1. Summary of VES analysis.

\begin{tabular}{|c|c|c|c|c|c|}
\hline \multirow{2}{*}{ VES stations } & \multicolumn{4}{|c|}{ Probable aquifer } & \multirow{2}{*}{ Aquifer type } \\
\hline & Resistivity $(\Omega \mathrm{m})$ & Thickness (m) & Depth (m) & Lithology & \\
\hline 1 & 397.72 & 28.57 & 30.35 & Clayey sand & Confined \\
\hline 2 & 748.01 & - & 29.33 & Fractured bedrock & Unconfined \\
\hline 3 & 534.71 & - & 13.29 & Clayey sand & Confined \\
\hline 4 & 379.28 & 3.20 & 4.93 & Clayey sand & Confined \\
\hline 5 & 527.85 & - & 20.18 & Clayey sand & Confined \\
\hline 6 & 991.52 & - & 14.33 & Fractured bedrock & Confined \\
\hline 7 & 734.35 & - & 12.02 & Fractured bedrock & Confined \\
\hline 8 & 347.82 & - & 9.77 & Clayey sand & Confined \\
\hline 9 & 600.39 & - & 31.43 & Clayey sand & Confined \\
\hline 10 & 23.73 & 11.11 & 14.69 & Shale/Clay & Confined \\
\hline 11 & 848.75 & - & 31.55 & Fractured bedrock & Confined \\
\hline 12 & 910.24 & - & $2.60 ? ?$ & Fractured bedrock & Confined \\
\hline 13 & 340.11 & 4.84 & 6.96 & Clayey sand & Unconfined \\
\hline 14 & 132.17 & 15.82 & 24.61 & Sandy clay & Unconfined \\
\hline 15 & 346.07 & 6.60 & 8.99 & Clayey sand & Confined \\
\hline 16 & 126.21 & 5.48 & $5.73 ? ?$ & Sandy clay & Unconfined \\
\hline 17 & 106.50 & 26.86 & 28.06 & Sandy clay & Unconfined \\
\hline 18 & 455.47 & 4.46 & 6.43 & Clayey sand & Confined \\
\hline 19 & 843.27 & - & 37.88 & Fractured bedrock & Confined \\
\hline 20 & 296.51 & 3.92 & 6.96 & Clayey sand & Confined \\
\hline 21 & 493.88 & 5.02 & 10.50 & Clayey sand & Confined \\
\hline 22 & 859.47 & 6.93 & 9.21 & Clayey sand & Confined \\
\hline 23 & 278.06 & 2.15 & 2.45 & Clayey sand & Unconfined \\
\hline 24 & 188.62 & 2.62 & 2.84 & Sandy clay & Unconfined \\
\hline 25 & 103.65 & 18.57 & 20.27 & Sandy clay & Unconfined \\
\hline 26 & 54.64 & 21.21 & 23.35 & Shale/Clay & Unconfined \\
\hline 27 & 895.56 & - & 19.14 & Fractured bedrock & Confined \\
\hline 28 & 387.59 & - & 24.50 & Clayey sand & Confined \\
\hline 29 & 548.97 & - & 28.06 & Fractured bedrock & Confined \\
\hline 30 & 37.62 & 8.25 & 9.92 & Shale/Clay & Unconfined \\
\hline 31 & 113.28 & 6.31 & 7.90 & Sandy clay & Unconfined \\
\hline 32 & 141.75 & 4.70 & 5.37 & Sandy clay & Unconfined \\
\hline 33 & 178.84 & - & 7.44 & Sandy clay & Confined \\
\hline 34 & 511.49 & - & 8.21 & Clayey sand & Confined \\
\hline
\end{tabular}

boreholes.

The principal source of recharge of groundwater can be falling precipitation that eventually percolates seepage from stream flow, lakes and reservoir, seepage from irrigation canals and purposeful application of water to augment groundwater supplies.

Basement aquifers are distinctive in that their occurrence and characteristics are largely a consequence of the interaction of weathering processes related to recharge and groundwater through flow (Wright, 1992).

The basement aquifer, even where continuous, has low permeability and the main groundwater flow systems are localized between recharge on watersheds to discharge by runoff or evaporation in valley bottomlands. All methods of estimating recharge are subject to considerable uncertainty (Simmers, 1988). This is generally more for basement aquifer as a result of their heterogeneity and the complex nature of the flow system (Simmers, 1988). Geology controls the rate of groundwater movement.

The size of the cracks in rocks, the size of the pores between soil and rock particles, and whether the pores are connected determine the rate at which water moves into, through and out of an aquifer. 
332 Afr. J. Environ. Sci. Technol.

Table 2. Summary of resistivity value, layer thickness and litholgy.

\begin{tabular}{|c|c|c|c|c|c|}
\hline VES station & Layer & Resistivity $(\Omega m)$ & Thickness (m) & Depth (m) & Lithology \\
\hline \multirow{4}{*}{1} & 1 & 122.88 & 0.77 & 0.77 & Topsoil \\
\hline & 2 & 31.80 & 1.01 & 1.78 & Shale/clay \\
\hline & 3 & 397.72 & 28.57 & 30.35 & Clayey sand \\
\hline & 4 & 1276.49 & & & Sandstone \\
\hline \multirow{3}{*}{2} & 1 & 19.69 & 0.26 & 0.26 & Topsoil \\
\hline & 2 & 149.41 & 29.07 & 29.33 & Sandy clay \\
\hline & 3 & 748.01 & & & Fractured bedrock \\
\hline \multirow{3}{*}{3} & 1 & 63.12 & 1.50 & 1.50 & Topsoil \\
\hline & 2 & 130.35 & 11.79 & 13.29 & Sandy clay \\
\hline & 3 & 534.71 & & & Clayey sand \\
\hline \multirow{5}{*}{4} & 1 & 130.75 & 1.30 & 1.30 & Topsoil \\
\hline & 2 & 18.92 & 0.43 & 1.73 & Clay /shale \\
\hline & 3 & 379.28 & 3.20 & 4.93 & Clayey sand \\
\hline & 4 & 4.18 & 1.15 & 6.08 & Shale/clay \\
\hline & 5 & 1023.76 & & & Sandstone \\
\hline \multirow{3}{*}{5} & 1 & 75.59 & 2.18 & 2.18 & Topsoil \\
\hline & 2 & 37.38 & 18.00 & 20.18 & Clay/shale \\
\hline & 3 & 527.85 & & & Clayey sand \\
\hline \multirow{4}{*}{6} & 1 & 221.45 & 0.98 & 0.98 & Topsoil \\
\hline & 2 & 612.42 & 2.11 & 3.09 & Clayey sand \\
\hline & 3 & 39.36 & 11.24 & 14.33 & Clay/shale \\
\hline & 4 & 991.52 & & & Fractured bedrock \\
\hline \multirow{3}{*}{7} & 1 & 293.72 & 0.91 & 0.91 & Topsoil \\
\hline & 2 & 37.45 & 11.11 & 12.02 & Clay/shale \\
\hline & 3 & 734.35 & & & Fractured bedrock \\
\hline \multirow{3}{*}{8} & 1 & 168.54 & 2.11 & 2.11 & Topsoil \\
\hline & 2 & 21.61 & 7.66 & 9.77 & Clay/shale \\
\hline & 3 & 347.82 & & & Clayey sand \\
\hline \multirow{4}{*}{9} & 1 & 115.34 & 1.09 & 1.09 & Topsoil \\
\hline & 2 & 54.93 & 3.85 & 4.94 & Shale/clay \\
\hline & 3 & 24.18 & 26.49 & 31.43 & Shale/clay \\
\hline & 4 & 600.39 & & & Clayey sand \\
\hline \multirow{4}{*}{10} & 1 & 346.93 & 0.43 & 0.43 & Topsoil \\
\hline & 2 & 105.77 & 3.15 & 3.58 & Sandy clay \\
\hline & 3 & 23.73 & 11.11 & 14.69 & Shale/clay \\
\hline & 4 & 5725.29 & & & Fresh bedrock \\
\hline \multirow{4}{*}{11} & 1 & 40.47 & 0.42 & 0.42 & Topsoil \\
\hline & 2 & 236.65 & 1.17 & 1.59 & Clayey sand \\
\hline & 3 & 39.23 & 29.96 & 31.55 & Shale/clay \\
\hline & 4 & 848.75 & & & Fractured bedrock \\
\hline
\end{tabular}


Table 2. Contd.

\begin{tabular}{|c|c|c|c|c|c|}
\hline \multirow{3}{*}{12} & 1 & 62.20 & 1.56 & 1.56 & Topsoil \\
\hline & 2 & 119.66 & 1.04 & 2.6 & Sandy clay \\
\hline & 3 & 910.24 & & & Fractured basement \\
\hline \multirow{3}{*}{13} & 1 & 128.12 & 2.12 & 2.12 & Topsoil \\
\hline & 2 & 340.11 & 4.84 & 6.96 & Clayey sand \\
\hline & 3 & 1039.58 & & & Sandstone \\
\hline \multirow{4}{*}{14} & 1 & 187.26 & 3.73 & 3.73 & Topsoil \\
\hline & 2 & 810.41 & 5.06 & 8.79 & Compacted clayey sand \\
\hline & 3 & 132.17 & 15.82 & 24.61 & Sandy clay \\
\hline & 4 & 2637.87 & & & Fresh bedrock \\
\hline \multirow{5}{*}{15} & 1 & 239.04 & 0.94 & 0.94 & Topsoil \\
\hline & 2 & 70.16 & 1.45 & 2.39 & Shale/clay \\
\hline & 3 & 346.07 & 6.60 & 8.99 & Clayey sand \\
\hline & 4 & 103.47 & 23.92 & 32.91 & Sandy clay \\
\hline & 5 & 1973.88 & & & Fresh bedrock \\
\hline \multirow{4}{*}{16} & 1 & 470.20 & 0.25 & 0.25 & Topsoil \\
\hline & 2 & 126.21 & 5.48 & 5.73 & Sandy clay \\
\hline & 3 & 59.12 & 4.53 & 10.26 & Shale/clay \\
\hline & 4 & 4016.34 & & & Fresh bedrock \\
\hline \multirow{3}{*}{17} & 1 & 887.32 & 1.20 & 1.20 & Topsoil \\
\hline & 2 & 106.50 & 26.86 & 28.06 & Sandy clay \\
\hline & 3 & 4750.50 & & & Fresh bedrock \\
\hline \multirow{5}{*}{18} & 1 & 142.42 & 0.78 & 0.78 & Topsoil \\
\hline & 2 & 67.39 & 1.19 & 1.97 & Shale/clay \\
\hline & 3 & 455.47 & 4.46 & 6.43 & Clayey sand \\
\hline & 4 & 76.87 & 14.98 & 21.41 & Shale/clay \\
\hline & 5 & 1156.37 & & & Fresh bedrock \\
\hline \multirow{5}{*}{19} & 1 & 96.03 & 0.32 & 0.32 & Topsoil \\
\hline & 2 & 345.60 & 0.65 & 0.97 & Clayey sand \\
\hline & 3 & 173.47 & 6.67 & 7.64 & Sandy clay \\
\hline & 4 & 41.61 & 30.24 & 37.88 & Shale/clay \\
\hline & 5 & 843.27 & & & Fractured bedrock \\
\hline \multirow{5}{*}{20} & 1 & 212.70 & 1.40 & 1.40 & Topsoil \\
\hline & 2 & 57.13 & 1.64 & 3.04 & Shale/clay \\
\hline & 3 & 296.51 & 3.92 & 6.96 & Clayey sand \\
\hline & 4 & 46.89 & 13.31 & 20.27 & Shale/clay \\
\hline & 5 & 1353.24 & & & Fresh bedrock \\
\hline \multirow{4}{*}{21} & 1 & 424.77 & 0.93 & 0.93 & Topsoil \\
\hline & 2 & 153.83 & 4.55 & 5.48 & Sandy clay \\
\hline & 3 & 493.88 & 5.02 & 10.5 & Clayey sand \\
\hline & 4 & 80.46 & & & Shale/clay \\
\hline
\end{tabular}


334 Afr. J. Environ. Sci. Technol.

Table 2. Contd.

\begin{tabular}{|c|c|c|c|c|c|}
\hline \multirow{4}{*}{22} & 1 & 217.67 & 1.65 & 1.65 & Topsoil \\
\hline & 2 & 51.97 & 0.63 & 2.28 & Shale/clay \\
\hline & 3 & 859.47 & 6.93 & 9.21 & Clayey sand \\
\hline & 4 & 85.77 & & & Shale/clay \\
\hline \multirow{4}{*}{23} & 1 & 42.89 & 0.30 & 0.30 & Topsoil \\
\hline & 2 & 278.06 & 2.15 & 2.45 & Clayey sand \\
\hline & 3 & 37.34 & 17.96 & 20.41 & Shale/clay \\
\hline & 4 & 1107.80 & & & sandstone \\
\hline \multirow{3}{*}{24} & 1 & 95.34 & 0.22 & 0.22 & Topsoil \\
\hline & 2 & 188.62 & 2.62 & 2.84 & Sandy clay \\
\hline & 3 & 82.02 & & & Shale/clay \\
\hline \multirow{4}{*}{25} & 1 & 71.95 & 0.38 & 0.38 & Topsoil \\
\hline & 2 & 273.55 & 1.32 & 1.7 & Clayey sand \\
\hline & 3 & 103.65 & 18.57 & 20.27 & Sandy clay \\
\hline & 4 & 3746.16 & & & Fresh bedrock \\
\hline \multirow{3}{*}{26} & 1 & 231.68 & 2.14 & 2.14 & Topsoil \\
\hline & 2 & 54.64 & 21.21 & 23.35 & Shale/clay \\
\hline & 3 & 1696.06 & & & Fresh bedrock \\
\hline \multirow{3}{*}{27} & 1 & 240.93 & 1.28 & 1.28 & Topsoil \\
\hline & 2 & 71.35 & 17.86 & 19.14 & Shale/clay \\
\hline & 3 & 895.56 & & & Fractured bedrock \\
\hline \multirow{4}{*}{28} & 1 & 121.84 & 1.00 & 1.00 & Topsoil \\
\hline & 2 & 68.73 & 8.88 & 9.88 & Shale/clay \\
\hline & 3 & 17.55 & 14.62 & 24.5 & Shale/clay \\
\hline & 4 & 387.59 & & & Clayey sand \\
\hline \multirow{4}{*}{29} & 1 & 56.33 & 0.36 & 0.36 & Topsoil \\
\hline & 2 & 183.57 & 6.23 & 6.59 & Sandy clay \\
\hline & 3 & 34.56 & 21.47 & 28.06 & Shale/clay \\
\hline & 4 & 548.97 & & & Fractured bedrock \\
\hline \multirow{4}{*}{30} & 1 & 341.64 & 0.75 & 0.75 & Topsoil \\
\hline & 2 & 2539.87 & 0.92 & 1.67 & Compacted sandstone \\
\hline & 3 & 37.62 & 8.25 & 9.92 & Shale/clay \\
\hline & 4 & 2644.44 & & & Fresh bedrock \\
\hline \multirow{3}{*}{31} & 1 & 316.83 & 1.59 & 1.59 & Topsoil \\
\hline & 2 & 113.28 & 6.31 & 7.9 & Sandy clay \\
\hline & 3 & 1289.14 & & & Fresh bedrock \\
\hline \multirow{4}{*}{32} & 1 & 105.50 & 0.18 & 0.18 & Topsoil \\
\hline & 2 & 796.69 & 0.49 & 0.67 & Compacted clayey sand \\
\hline & 3 & 141.75 & 4.70 & 5.37 & Sandy clay \\
\hline & 4 & 2016.07 & & & Fresh bedrock \\
\hline
\end{tabular}


Table 2. Contd.

\begin{tabular}{llllll}
\hline & 1 & 227.57 & 3.07 & 3.07 & Topsoil \\
Compacted sandstone \\
Sandy clay
\end{tabular}

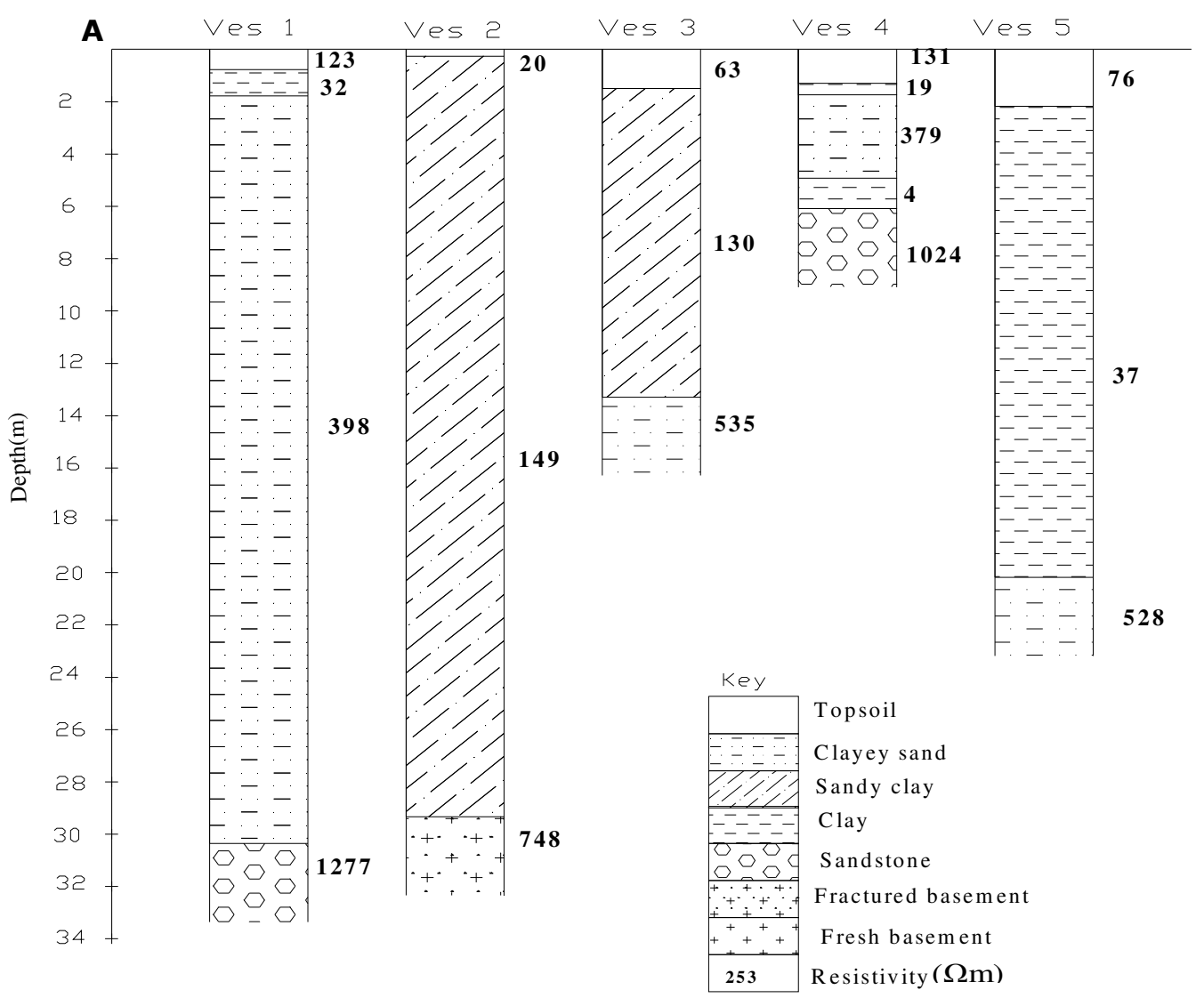

$A^{\prime}$

Figure 3a. Geoelectric sections beneath profile AA'. 
Afr. J. Environ. Sci. Technol.

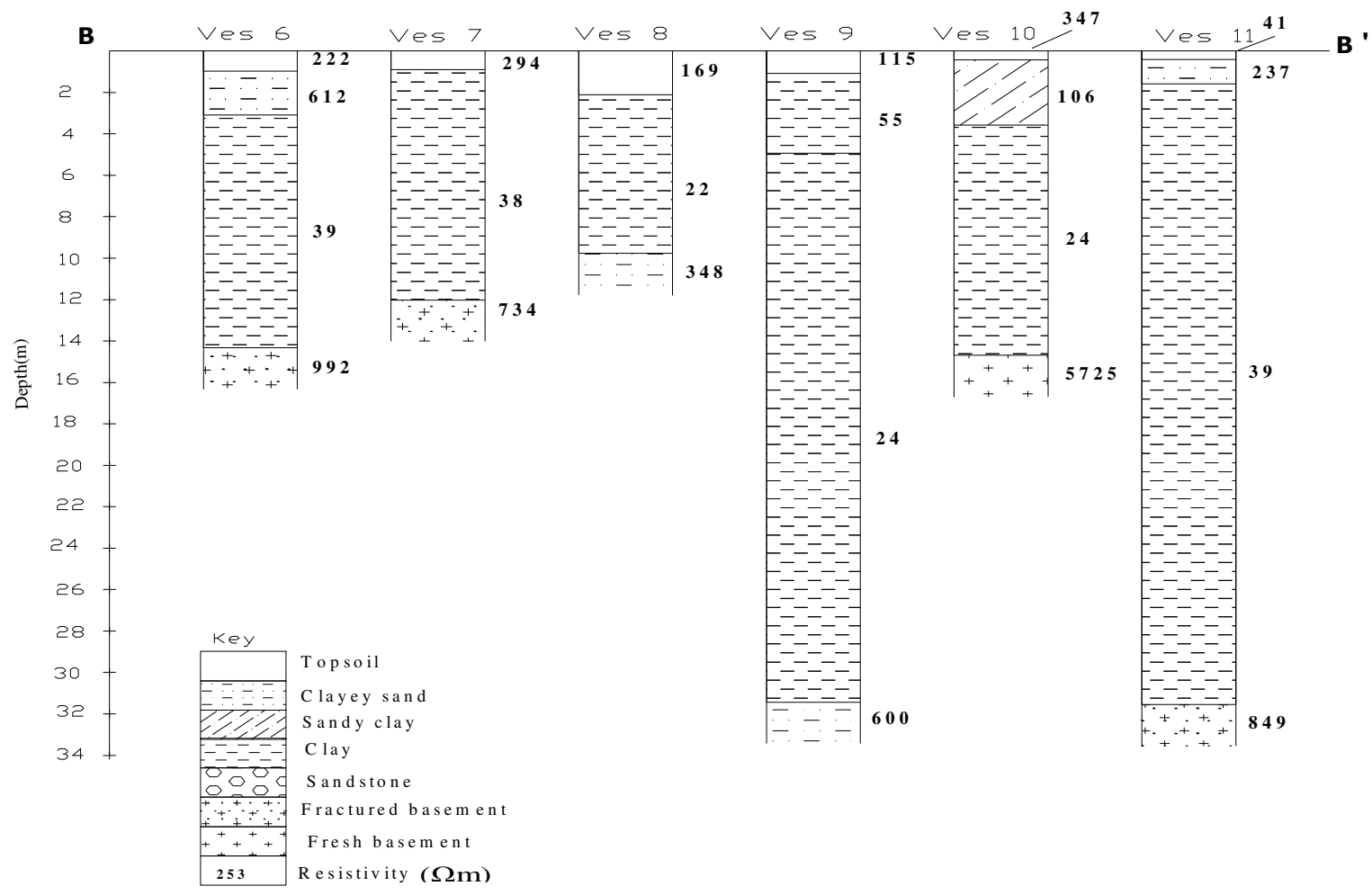

Figure 3b. Geoelectric sections beneath profile BB'.

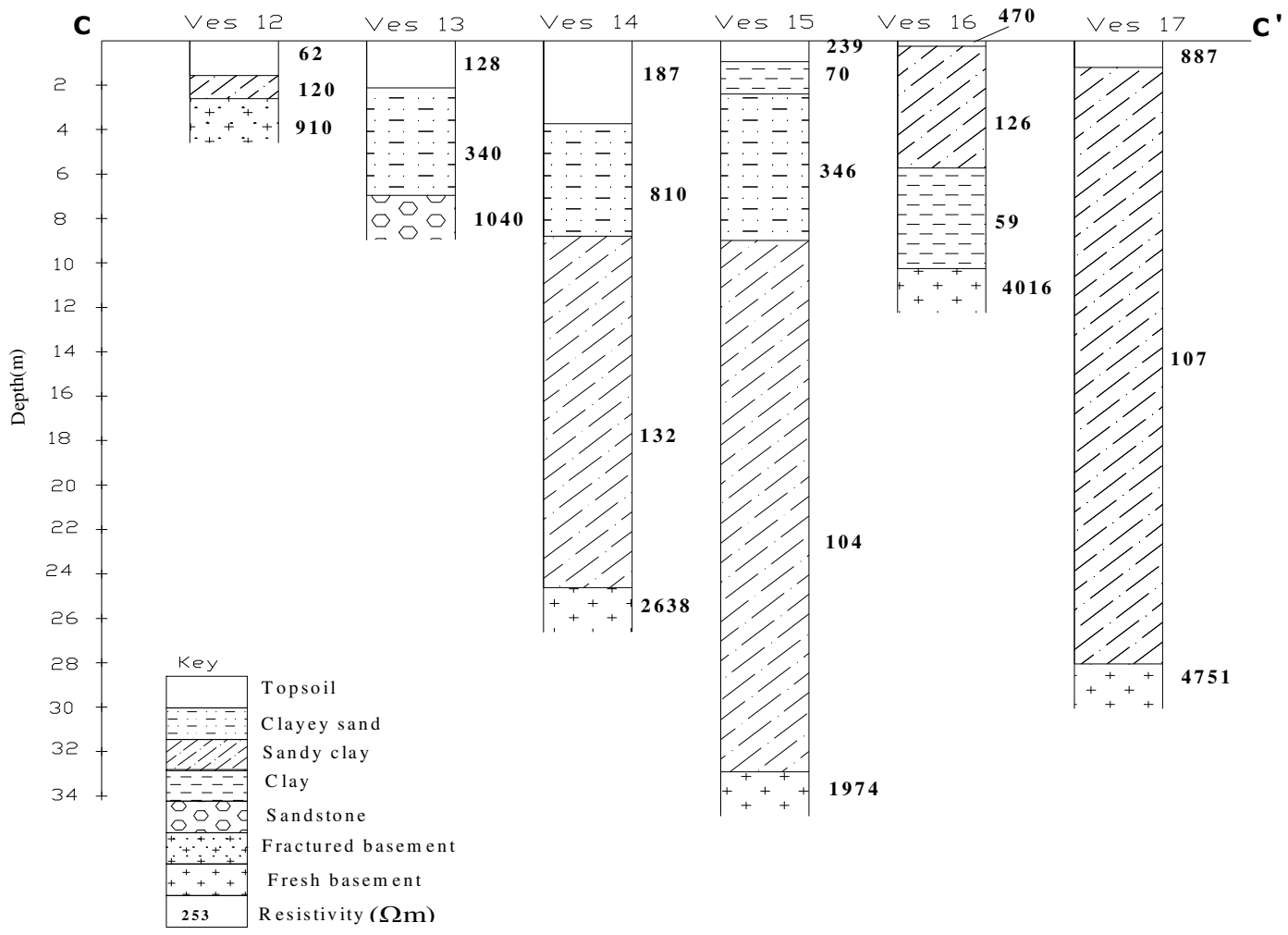

Figure 3c. Geoelectric sections beneath profile CC'. 


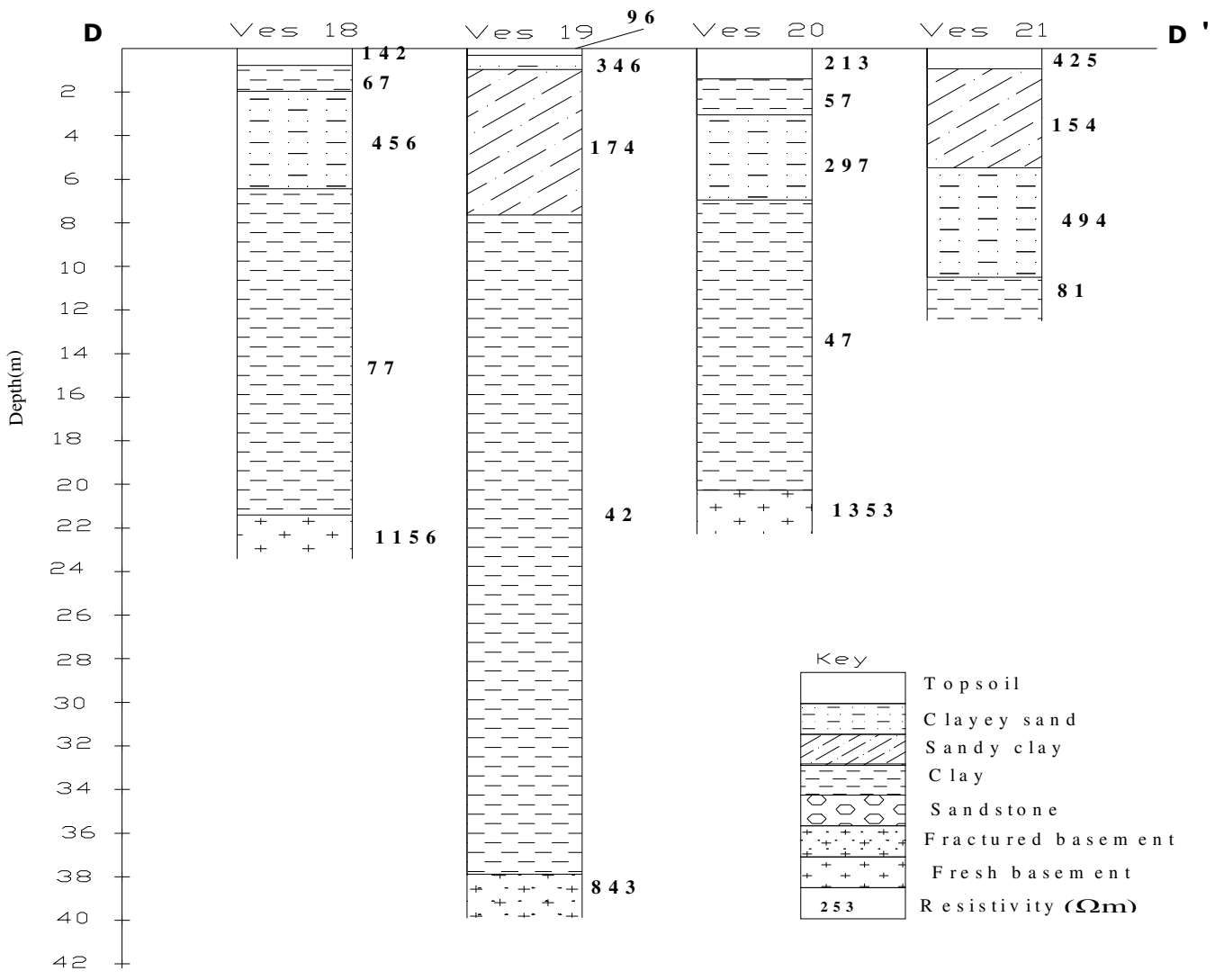

Figure 3d. Geoelectric sections beneath profile DD'.

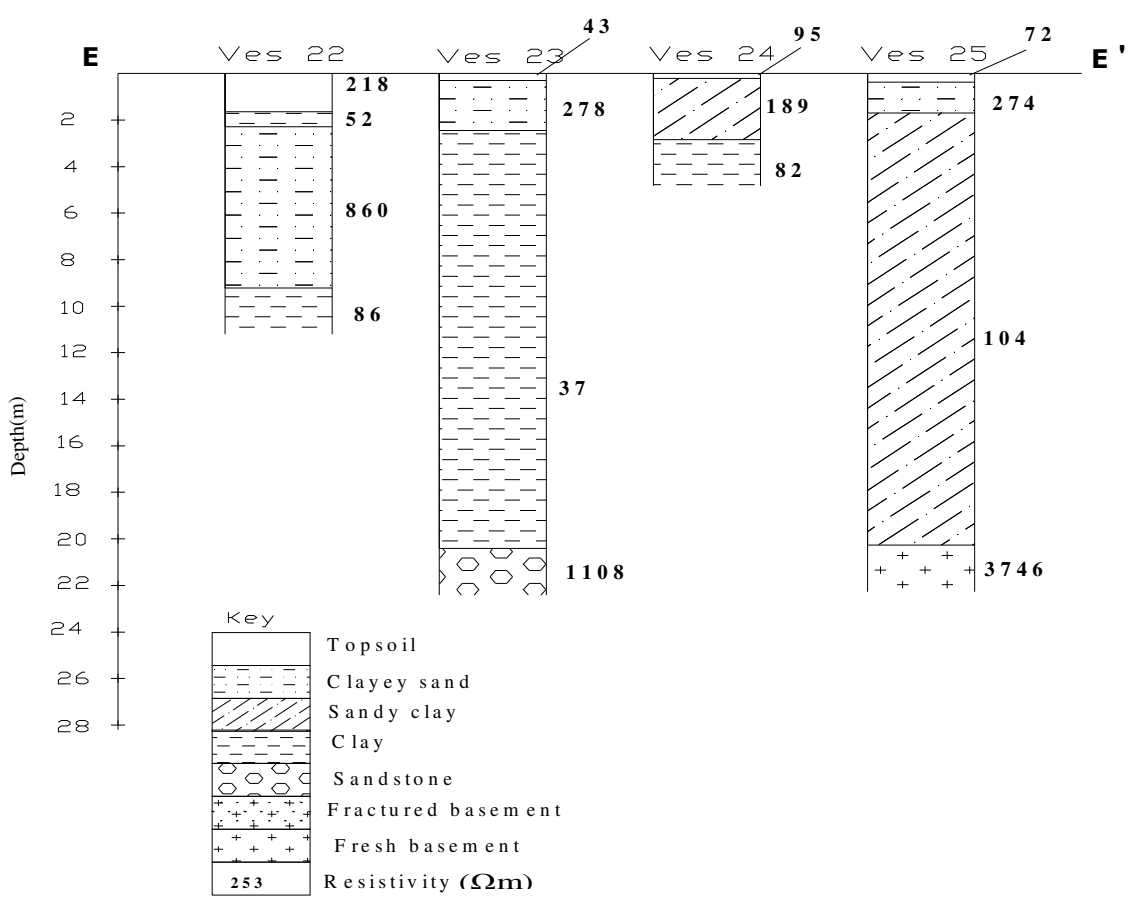

Figure 3e. Geoelectric sections beneath profile EE'. 
338 Afr. J. Environ. Sci. Technol.

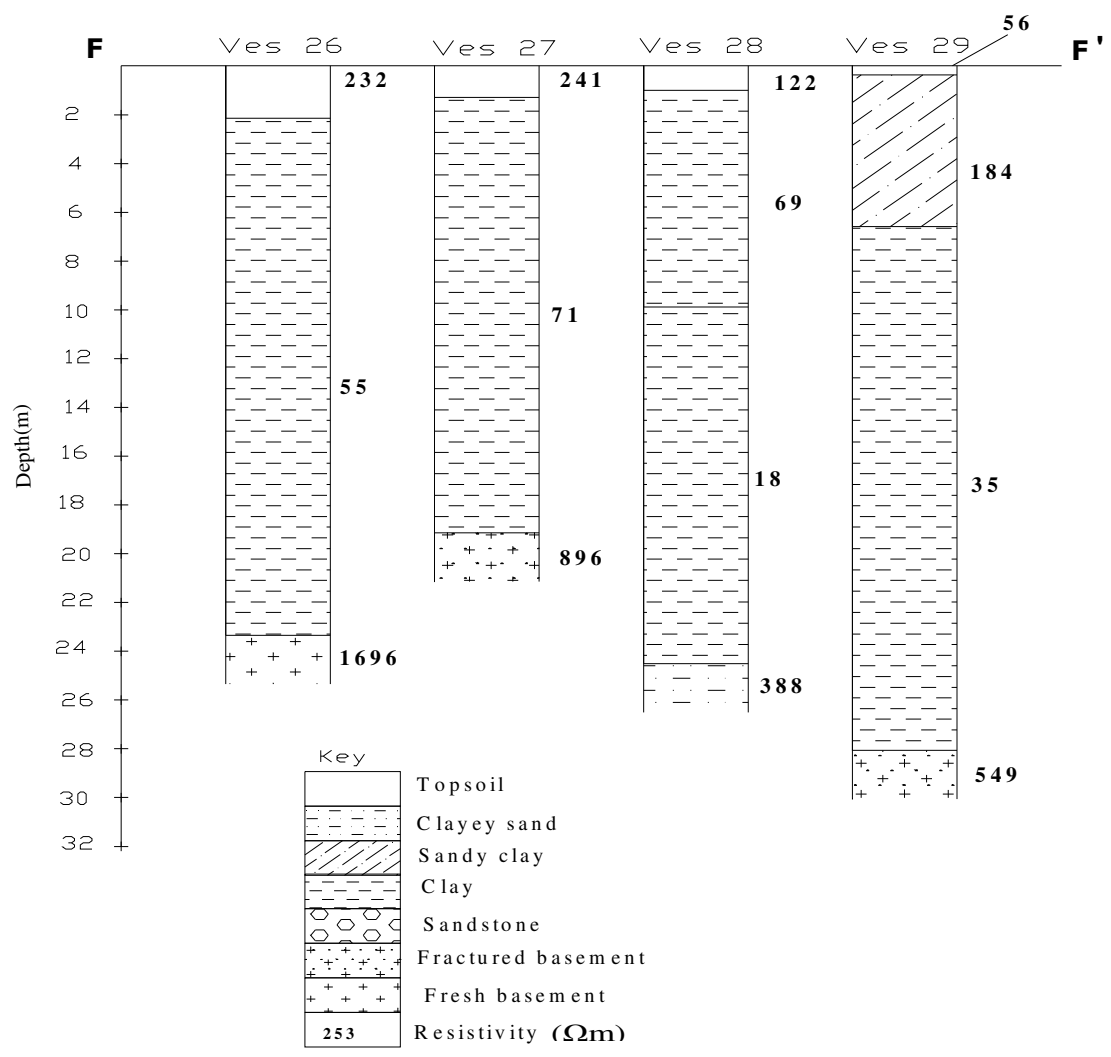

Figure 3f. Geoelectric sections beneath profile FF'.

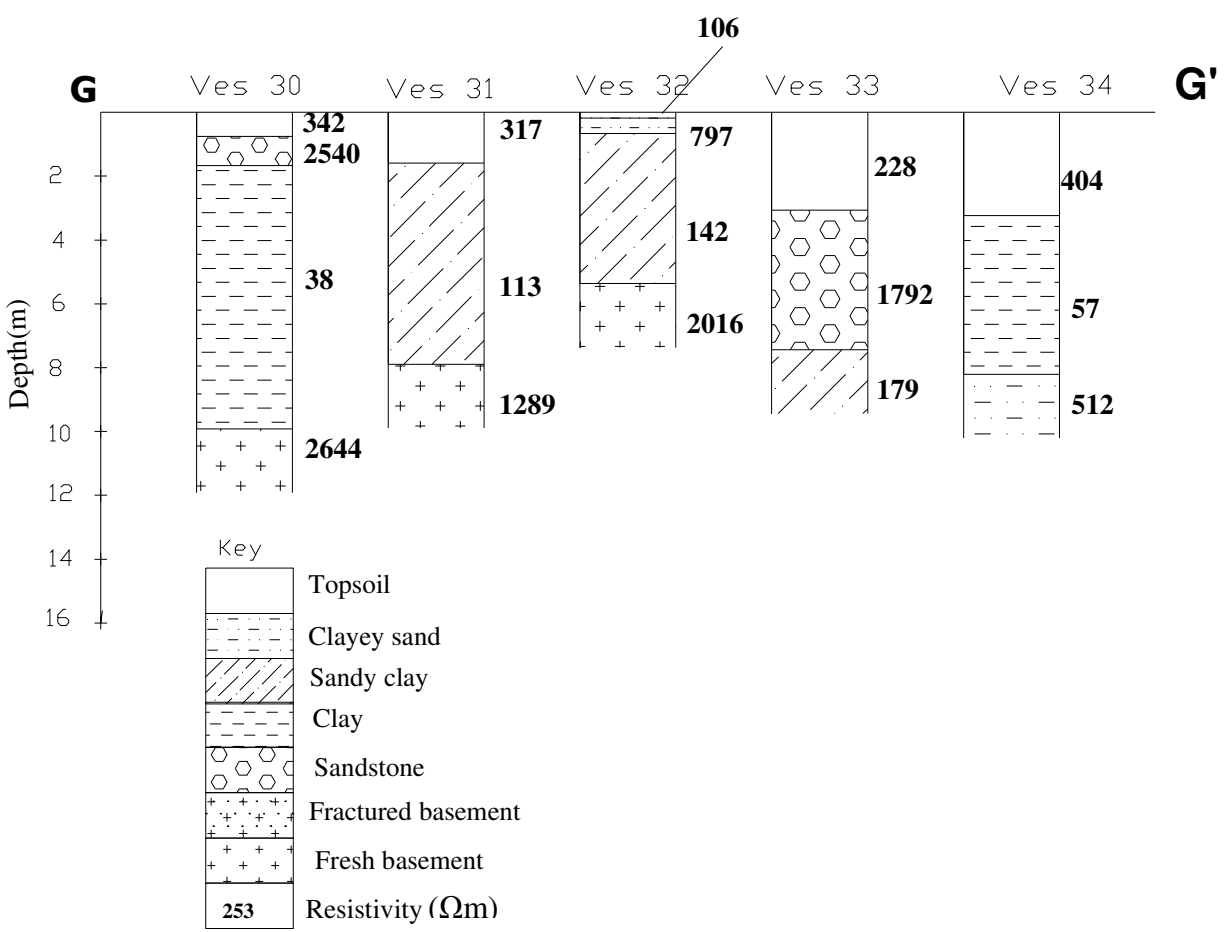

Figure 3g. Geoelectric sections beneath profile GG'. 

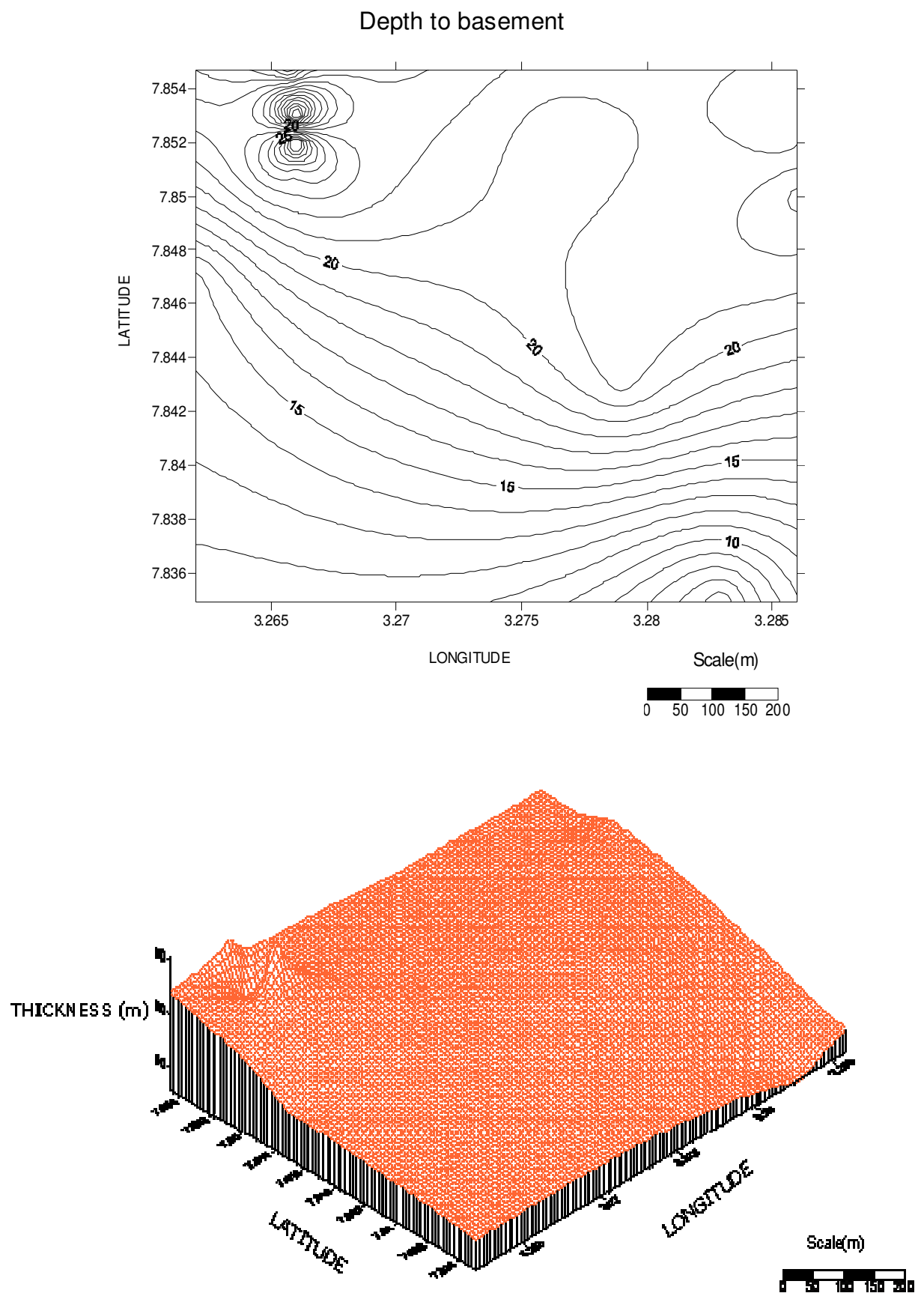

Figure 4a. Contour maps showing depth to basement and 3-D view.

The recharge of the existing boreholes in the study area is largely due to falling precipitation. Three boreholes are located close to VES 1 - 5 along profile AA. $\mathrm{BH} 1$ is characterized by unconfined aquifer. Water is prevented from entering or discharged from the aquifer. $\mathrm{BH} 2$ and $\mathrm{BH} 3$ have very good yield because the groundwater is confined under pressure between relatively impermeable materials.

\section{Contour maps and 3-D view}

Contour technique was also used for the interpretation of the resistivity values obtained from the field data, using "Suffer soft ware". Three types of contour maps (depth to basement, overburden thickness and aquifer thickness) were prepared as well as the 3-dimensional views (Figures $4 a-4 c$ ). The depth to basement map shows the 


\section{Overburden thickness}
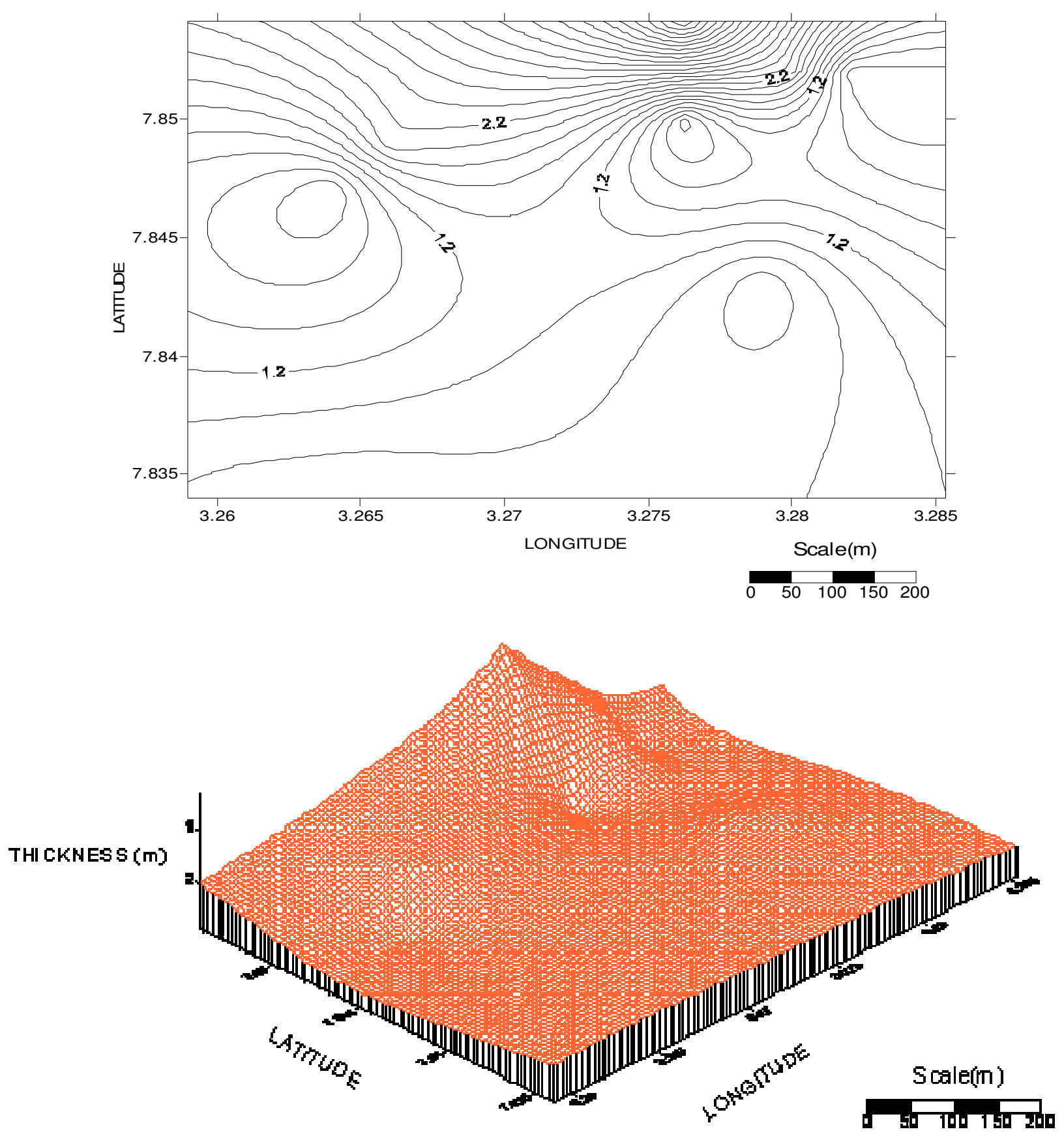

Figure 4b. Contour maps showing overburden thickness and 3-D view.

various total depths of the VES locations while the overburden thickness contour map (Figure 4b) depicts clearly the depth to the aquifer. This shows the area of thick overburden/depression along different profiles. The aquifer thickness map (Figure 4c) depicted various types of aquifer found in all VES locations sounded, an indication of what the groundwater accumulation would be as well as the degree of recharging.

\section{Conclusion}

The geophysical investigation carried out at the Federal College of Education, Osiele, Abeokuta, Nigeria has revealed seven major geologic formations. These are topsoil, shale/clay, sandy clay, clayey sand, sandstone, fractured basement and fresh basement. The weathered and fractured basement constitutes the main aquiferous 
Aquifer thickness
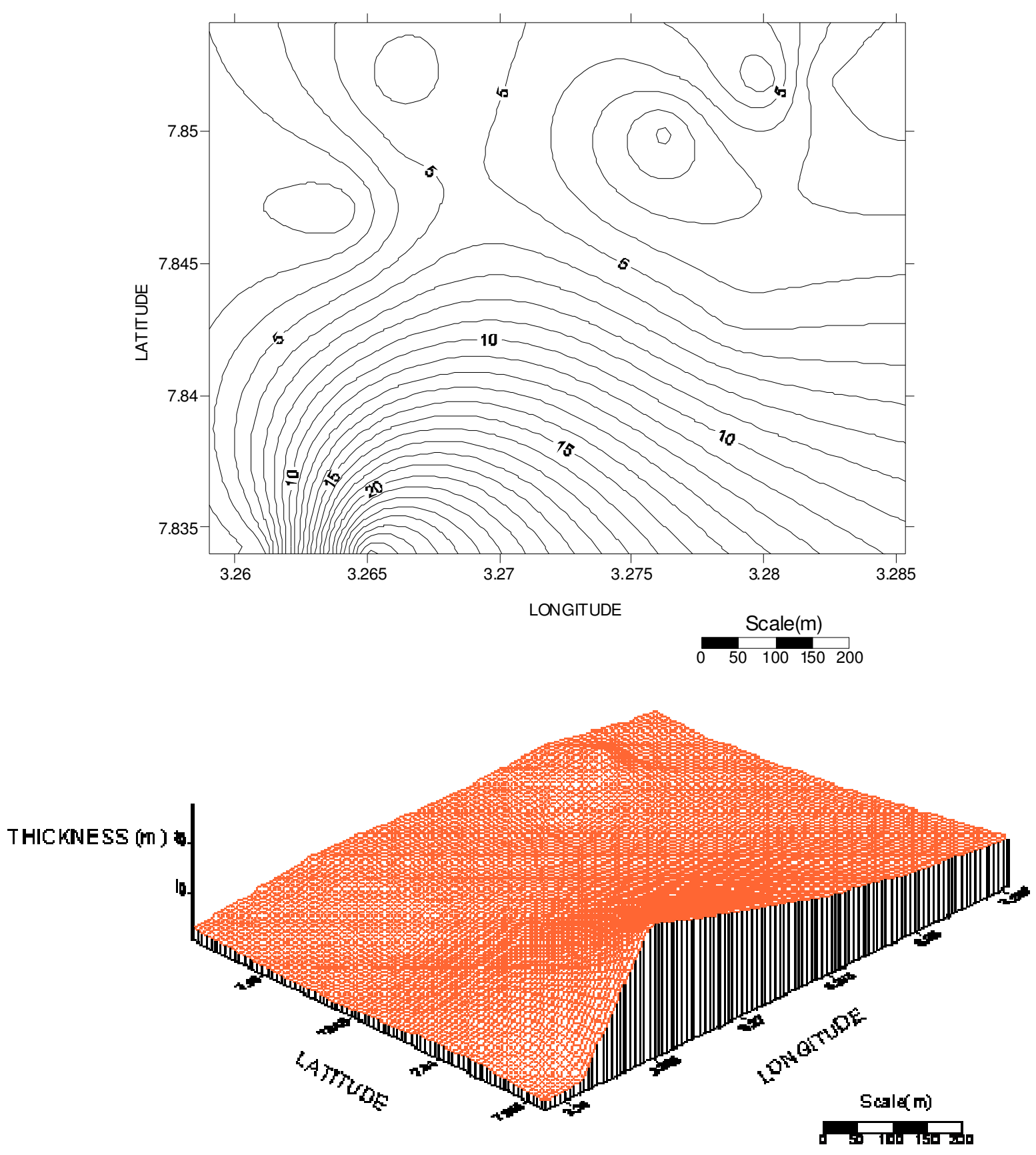

Figure 4c. Contour Maps Showing Overburden thickness and 3-D View.

units in the area. The reasons for borehole failure and poor recharge may be attributed to inadequate geophysical investigation, the depth at which drilling was terminated and the geologic formation of the aquifers. Thus a thorough geophysical survey of this area is necessary so as to determine suitable location for groundwater exploration.

The recommended depth for borehole in basement areas are usually within 35 and $70 \mathrm{~m}$ as reported in literature. Therefore good prospect exist for groundwater development in most of the locations surveyed in study area. Such locations include VES 1, 2, 5, 9, 11, 19, 28 and 29 and this is because the depths to weathered layer (clayey sand)/fractured layer falls within the depth range of 20 to $38 \mathrm{~m}$.

However, locations around VES 10,26 and 30 are not 
recommended for borehole drilling because the weathered layers, even though with appreciable thickness are composed of shale/clay. This is because shale/ clay is an aquitard, which makes groundwater exploration difficult.

\section{ACKNOWLEDGEMENT}

This research work has been reviewed by Professor Olasunbo Martins of the Department of Water Resources Management and Agro Meteorology of the University of Agriculture, Abeokuta, Nigeria and Dr. Elijah Adebowale Ayolabi of the Department of Physics, University of Lagos, Akoka, Lagos, Nigeria.

\section{REFERENCES}

Clark $L$ (1985). Groundwater abstraction from basement complex areas of Africa. Quarterly J. Eng. Geol. 18: 25-34.

Jones HA, Hockey RD (1964). The geology of parts of Southwestern Nigeria. Geol. Survey Niger. Bull. 31: 22-24.
Lyford FP (2004). A conceptual framework for predicting sustainable well yields in crystalline-rock aquifers, examples from Massachusetts. In Proceeding of 2004 Annual Meeting of the Geological Society of America, Philadelphia, Pennsylvania, 25-27 March 2004.

Manda AK, Mabee SB, Boutt DF (2006). Characterizing fractured crystalline bedrock aquifers using hydrostructural domains in the Nashoba terrane, Eastern Massachusetts. In Proceeding of 2006 Annual Meeting of the Geological Society of America, Philadelphia, Pennsylvania, 22-25 October 2006.

Rahman MA (1989). Review of the Basement Geology of Southwest, Nigeria. Geol. Nigeria pp. 943-959.

Simmers I (ed.) (1988). Estimation of Natural Groundwater Recharge. Reidel, Dordrecht, NATO Advanced Study inst., 222.

Talkington RW (2004). Groundwater availability in fractured crystalline bedrock: Example from the seacoast of New Hampshire. In: Proceeding of 2004 Annual Meeting of the Geological Society of America, Philadelphia, Pennsylvania, 25-27 March 2004.

Wright EP (1992). The hydrogeology of crystalline basement aquifers in Africa. Geological Society, London, special Publications, 66, pp.1-27.

WingLink 1998-2003: Geosystem SRL, 17 Viale Abruzzi, Ital: www.geosystem.net 